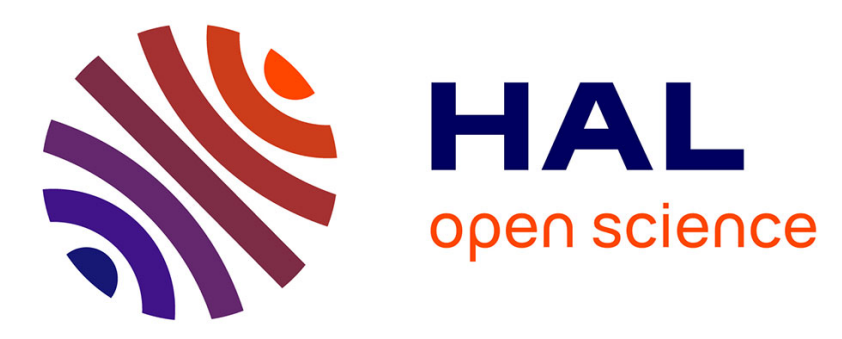

\title{
Nickel drives the bacterial community diversity in the rhizosphere of the hyperaccumulator Alyssum murale
}

Severine Lopez, Séverine Piutti, Jessica Vallance, Jean-Louis Morel, Guillaume Echevarria

\section{To cite this version:}

Severine Lopez, Séverine Piutti, Jessica Vallance, Jean-Louis Morel, Guillaume Echevarria. Nickel drives the bacterial community diversity in the rhizosphere of the hyperaccumulator Alyssum murale. XXVIII International Mineral Processing Congress, Sep 2016, Québec, Canada. 2016. hal-01263576

\section{HAL Id: hal-01263576 \\ https://hal.science/hal-01263576}

Submitted on 2 Jun 2020

HAL is a multi-disciplinary open access archive for the deposit and dissemination of scientific research documents, whether they are published or not. The documents may come from teaching and research institutions in France or abroad, or from public or private research centers.
L'archive ouverte pluridisciplinaire HAL, est destinée au dépôt et à la diffusion de documents scientifiques de niveau recherche, publiés ou non, émanant des établissements d'enseignement et de recherche français ou étrangers, des laboratoires publics ou privés. 


\title{
NICKEL DRIVES THE BACTERIAL COMMUNITY DIVERSITY IN THE RHIZOSPHERE OF THE HYPERACCUMULATOR ALYSSUM MURALE
}

\author{
S. Lopez ${ }^{1,2}$, S. Piutti ${ }^{3,4}$, J. Vallance ${ }^{5}$, J. L. Morel ${ }^{1,2}$, G. Echevarriaa ${ }^{1,2}$, E. Benizri ${ }^{1,2}$ \\ ${ }^{1}$ Laboratoire Sols et Environnement, Université de Lorraine, UMR 1120, 2 avenue de la Forêt de Haye, TSA \\ 40602, Vandoeuvre-lès-Nancy, F-54518, France. \\ ${ }^{2}$ INRA, Laboratoire Sols et Environnement, UMR 1120, 2 avenue de la Forêt de Haye, TSA 40602, Vandoeuvre- \\ lès-Nancy, F-54518, France. \\ ${ }^{3}$ Laboratoire Agronomie et Environnement, Université de Lorraine, UMR 1121, 2 avenue de la Forêt de Haye, TSA \\ 40602, Vandoeuvre-lès-Nancy, F-54518, France. \\ ${ }^{4}$ INRA, Laboratoire Agronomie et Environnement, UMR 1121, 2 avenue de la Forêt de Haye, TSA 40602, \\ Vandoeuvre-lès-Nancy, F-54518, France. \\ ${ }^{5}$ UMR SAVE (1065) - INRA/Bordeaux Sciences Agro, 71 Avenue Edouard Bourlaux, CS 20032, Villenave \\ d’Ornon, F-33882, France
}

Serpentine (ultramafic) soils display high concentrations of nickel (Ni). Nickel hyperaccumulators have evolved on such environments, developed physiological adaptations to metals (concentrations of Ni sometimes above 1\% in plant aerial biomass) and can be used for phytomining. Rhizosphere bacterial communities associated with Nihyperaccumulator plants differ from those of non-accumulating plants growing at the same site, and are also characterised by a higher number of Ni-tolerant bacteria. Alyssum murale, a Ni-hyperaccumulator, is commonly found on ultramafic soils around the Mediterranean. For a more efficient phytomining, we should characterize rhizosphere microorganisms of these plants, to find good indicators for the success of Ni extraction and to select interesting PGPR.

However, most studies have focused on analyzing soils with techniques that provide little detail about the phylogenetic structure of the bacterial communities. Alyssum murale can grow on non-ultramafic soils as well, with an altitudinal extension ranging from sea level to 2000 m.a.s.l. Among edaphic factors that could influence the phylogenetic structure of the bacterial communities, altitude and Ni bioavailability could be significant. Our objectives were to understand the specific changes in the structure of $A$. murale rhizosphere bacterial community that occur across two gradients: 1) elevation and 2) bioavailable Ni. We used pyrosequencing technique (454pyrosequencing of $16 \mathrm{~S}$ rRNA gene) to characterize bacterial communities in soils from $A$. murale rhizosphere.

On one hand we found a high proportion of Chloroflexi (greater than 50\%). Moreover, the higher the soil Ni contents, the more the relative abundance of Proteobacteria and Actinobacteria. On the contrary, the abundance of TM7 decreased with increasing levels of bioavailable Ni. On the other hand, we screened Ni-resistant bacteria having 1-aminocyclopropane-1-carboxylate deaminase (ACCd) activity for developing primers targeting the acdS gene. Quantification of ACCd activity- which is known to stimulate the growth of A murale- directly from soil DNA extracted could be an appropriate tool to predict phytomining efficiency.

\section{KEYWORDS}

Nickel, Hyperaccumulator, bacterial diversity, rhizosphere, pyrosequencing 